Muscle biopsy and muscle culture in a patient with gout. J. Neurol. Sci. 47: 191-202; 1980.

18. Sammons, D. W, Chilson, O. P. AMP deaminase: stage-specific isozymes in differentiating chick muscle. Arch. Biochem. Biophys. 191: 561-570; 1978.

19. Meienhofer, M. C. Askanas, V,; Proux-Daegelen, M. S.; Dreyfus, J. C.; Engel, W. K. Muscletype phosphorylase activity present in muscle cells cultured from three patients with myophosphorylase deficiency. Arch. Neurol. 34: 779-781; 1977.

20. Sato, K.; Imai, F.; Hatayama, I.; Roelofs, R. I. Characterization of glycogen phosphorylase iso- enzymes present in cultured skeletal muscle from patients with McArdle's disease. Biochem. Biophys. Res. Commun. 78: 663-668; 1977.

21. DiMauro, S.; Arnold, S.; Miranda, A.; Rowland, L. P. McArdle disease: the mystery of reappearing phosphorylase activity in muscle culture-a fetal isoenzyme. Ann. Neurol. 3: 60-66; 1978.

22. Osame, M.; Engel, A. G.; Rebouche, C. J.; Scott, R. E. Freeze-fracture electron microscopic analysis of plasma membranes of cultured muscle cells in Duchenne dystrophy. Neurology (NY) 31: 972-979; 1981 .

This study was supported by research grants AM27451 and NS06277 from the National Institutes of Health and by a Research Center Grant from the Muscular Dystrophy Association.

\title{
ERRATA
}

\section{Amino Acid and Energy Requirements for Rat Hepatocytes in Primary Culture.}

Per E. Schwarze, Anne E. Solheim, and Per O. Seglen

Vol. 18, No. 1, page 44. In Table 1 the legend for Final Concentrations should be $\mu M$, not $m M$; the Final Concentration for $\mathrm{KCl}$ under $\mu M$ should be 5000.00 , not 500.00 . On page 45 , Chemicals. should be $\left[{ }^{14} \mathrm{C}\right]$ Valine (CFB $75 ; 50 \mu \mathrm{Ci} / \mathrm{ml}$ ), not $\left[{ }^{14} \mathrm{C}\right]$ Valine $(\mathrm{CFB} 75 ; 50 \mu \mathrm{Ci} / \mathrm{mol}$ ). 